\title{
Considering a Neoproterozoic Snowball Earth
}

Paul F. Hoffman et al. (1) developed a modified "snowball Earth" hypothesis (2) to explain the association of Neoproterozoic lowlatitude glaciation with the deposition of "cap carbonate" rocks bearing highly depleted carbon isotopic values $\left(\delta^{13} \mathrm{C} \leq-5 \%\right)$. According to Hoffman et al., the ocean became completely frozen over as a result of a runaway albedo feedback, and primary biological productivity collapsed for an interval of geological time exceeding the carbon residence time $\left(>10^{5}\right.$ years). During this interval, continental ice cover is inferred to have been thin and patchy owing to the virtual elimination of the hydrological cycle.

These ideas are worthy of serious scrutiny, and we would like to discuss geological difficulties not addressed in an earlier Letter to the Editor (3). Climatological considerations suggest that snowball conditions would have developed gradually, probably over a span of $10^{6}$ to $10^{7}$ years. The widespread distribution of Sturtian ( $\sim 750$ to 700 $\mathrm{Ma})$ and Marinoan $(\sim 600$ to $575 \mathrm{Ma})(4,5)$ glacial deposits, in places thousands of meters thick (6), as well as evidence for $\geq 160 \mathrm{~m}$ drawdown of sea level for the Marinoan event (7), indicate a vigorous hydrological cycle, with marked erosion beneath large ice sheets and deposition under generally temperate conditions at and adjacent to ice margins (8). Catastrophic termination of snowball conditions interpreted by Hoffman et al. requires the bulk of these sediments to have accumulated before or during the interval in which the ocean was frozen because rapid melt out from any residual glacial ice, even thick glacial ice, would have left only a veneer of glacial and glacially derived sediments. However, gradual retreat of the ice front is recorded in many areas by tens to hundreds of meters of glacial deposits, in some cases with abundant outwash sediments (7-9). The time scale for this retreat is conservatively estimated in Australia as $>10^{4}$ to $10^{5}$ years, and most likely $>10^{5}$ years, on the basis of reversals in magnetic polarity in Marinoan outwash sandstones (10). This scenario suggests that if the ocean surface were completely frozen, it must have become unfrozen well before the end of glaciation.

If highly depleted carbon isotopic values of cap carbonates are the result of the collapse of primary productivity, then maximum depletion of the ocean as a whole ought to date from the time at which the ocean was frozen. However, in Namibia $(1,5)$, isotopic depletion increases up section from the base of the cap carbonate (a trend that is typical of
Marinoan cap carbonates) $(5,11)$. Hoffman et al. ascribe this trend to isotopic fractionation associated with the hydration of atmospherically derived $\mathrm{CO}_{2}$ in the surface ocean, with depletion returning to bulk oceanic values as the amount of $\mathrm{CO}_{2}$ in the atmosphere subsided from $\sim 0.12$ to 0.001 bar. This interpretation requires the ocean to have remained effectively lifeless for an unduly long span after snowball conditions had ceased-comparable to the duration of Marinoan deglaciation in Australia, including whatever time was needed for the drawdown of $\mathrm{CO}_{2}$ by continental weathering $\left(10^{4}\right.$ to $10^{6}$ years?) (12) and for deposition of the cap carbonates $\left(<10^{5}\right.$ years $)(13)$

Nicholas Christie-Blick
Linda E. Sohl
Department of Earth and Environmental
Sciences and
Lamont-Doherty Earth Observatory of
Columbia University,
Palisades, NY 10964-8000, USA
E-mail: ncb@ldeo.columbia.edu
Martin J. Kennedy
Exxon Production Research Company,
Post Office Box 2189,
Houston, TX 77252-2189, USA

\section{References and Notes}

1. P. F. Hoffman, A. J. Kaufman, G. P. Halverson, D. P. Schrag, Science 281, 1342 (1998).

2. J. L. Kirschvink, in The Proterozoic Biosphere, J. W. Schopf and C. Klein, Eds. (Cambridge Univ. Press, Cambridge, 1992), pp. 51-52.

3. G. S. Jenkins and C. R. Scotese, Science 282, 1644 (1998).

4. K. V. Evans, K. Lund, J. N. Aleinikoff, C. M. Fanning Geol. Soc. Am. Abstr. Programs 29 (no. 6), 196 (1997); A. J. Kaufman, A. H. Knoll, G. M. Narbonne, Proc. Natl. Acad. Sci. U.S.A. 94, 6600 (1997); S. A Bowring and D. H. Erwin, GSA Today 8 (no. 9), 1 (1998); P. F. Hoffman, A. J. Kaufman, G. P. Halverson ibid., p. 1; B. Z. Saylor, A. J. Kaufman, J. P. Grotzinger, F. Urban, J. Sediment. Res. 68, 1223 (1998).

5. M. J. Kennedy, B. Runnegar, A. R. Prave, K.-H. Hoffmann, M. A. Arthur, Geology 26, 1059 (1998)

6. M. J. Hambrey and W. B. Harland, Eds., Earth's PrePleistocene Glacial Record (Cambridge Univ. Press, Cambridge, 1981); Palaeogeogr. Palaeoclimat. Palaeoecol. 51, 255 (1985); N. Eyles, Earth-Sci. Rev. 35, 1 (1993).

7. N. Christie-Blick, Brigham Young Univ. Geol. Studies 23, 1 (1997).

8. M. B Edwards, Sedimentology 22, 75 (1975); Norges Geol. Unders. Bull. 394, 1 (1984); N. Christie-Blick, in Glacial-Marine Sedimentation, B. F. Molnia, Ed. (Plenum, New York, 1983), pp. 703-776; M. Deynoux Palaeogeogr. Palaeoclimat. Palaeoecol. 51, 97 (1985); N. M. Lemon and V. A. Gostin, in The Evolution of a Late Precambrian-Early Palaeozoic Rift Complex: The Adelaide Geosyncline, J. B. Jago and P. S Moore, Eds. (Geological Society of Australia, Spec. Publ. 16, Sydney, Australia, 1990), pp. 149-163; G. M. Young and V. A. Gostin, in Glacial Marine Sedimentation; Paleoclimatic Significance, J. B. Anderson and
G. M. Ashley, Eds. (Geological Society of America, Spec. Publ. 261, Boulder, CO, 1991), pp. 207-222.

9. In marginal areas of sedimentary basins, most glacial sediment accumulates during retreat of the ice sheet [C. H. Eyles, N. Eyles, A. D. Miall, Palaeogeogr. Palaeoclimat. Palaeoecol. 51, 15 (1985); N. Eyles and C. H. Eyles, in Facies Models: Response to Sea Level Change, R. G. Walker and N. P. James, Eds. (Geological Association of Canada, St. John's, Canada, 1992), Pp. 73-100; J. M. G. Miller, in Sedimentary Environments: Processes, Facies and Stratigraphy, H. G. Reading, Ed. (Blackwell, Oxford, UK, ed. 3, 1996), pp. 454-484].

10. L. E. Sohl, Geol. Soc. Am. Abstr. Programs 29 (no. 6), 195 (1997); L. E. Sohl, N. Christie-Blick, D. V. Kent, Geol. Soc. Am. Bull., in press.

11. M. J. Kennedy, J. Sediment. Res. 66, 1050 (1996).

12. The high concentration of dissolved $\mathrm{CO}_{2}$ would at first have precluded the precipitation of carbonate in the ocean.

13. M. J. Kennedy and N. Christie-Blick, paper presented at SEPM-IAS Research Conference in Sicily, Italy, 15 to 19 September 1998.

14. We thank L. A. Derry and J. Lynch-Stieglitz for reviews, and W. S. Broecker, P. E. Olsen and S. R. Hemming for discussions. This comment was written following a seminar presented by P. F. Hoffman at Lamont on 15 January 1999. We thank Hoffman for the vigorous discussion that his visit inspired. Our research in Neoproterozoic geology has been supported by NSF grants EAR 92-06084, EAR 94-18294, and EAR 96-14070.

9 February 1999; accepted 26 March 1999

Response: Christie-Blick et al. point out that Neoproterozoic glacial deposits in Australia and North America differ in many respects from those we reported in Namibia (1). This calls for a modification of one statement in our characterization of a snowball Earth, so as to account for geological observations in areas of contrasting paleogeography. In addition, Christie-Blick et al. question our interpretation of the carbon isotopic records in Namibia $(1,2)$.

In our original report (1), we inferred that when the world ocean was covered by sea ice (as a result of runaway ice-albedo feedback), "continental ice cover was thin and patchy because of the virtual elimination of the hydrologic cycle" (1). Unlike the Ghaub glaciation in Namibia, on which we based our report, Neoproterozoic glacial deposits in Australia and North America are locally thick $(>1 \mathrm{~km})$, fill incised paleovalleys $(<150 \mathrm{~m}$ deep), contain faceted and striated stones, have associated outwash deposits, and record as many as six magnetic polarity reversals ( 3 , $4,5)$. These features indicate that substantial amounts of flowing ice existed on land for time scales of $10^{6}$ years. Some of this flowing ice may be ascribed to conventional glaciation preceeding a snowball Earth, given that ice lines must reach $\sim 35^{\circ}$ latitude before an ice-albedo runaway can occur (6), but the Marinoan glacial deposits in Australia cannot be accounted for in this way because they formed near sea level at $<8^{\circ}$ paleolatitude ( 5 , 7). In fact, a limited hydrologic cycle would still exist in a snowball Earth because of sublimation of sea ice in the tropics and slow accretion of ice at higher elevations (depending on lapse rate) and higher latitudes. Given 


\section{TECHNICALCOMMENT}

the estimated bounds of 4 and 30 My for the duration of a snowball Earth (1), net accretion rates as low as 1.0 or $0.1 \mathrm{~mm} /$ year, respectively, would suffice to form glaciers 3 to 4 $\mathrm{km}$ thick, which would flow gravitationally and transport sediment. Direct glacial delivery of sediment to the ocean would account for the predominance of subaqueous outwash deposits (4). Sections of tidal rhythmites interpreted to have accumulated in shallow water near the paleo-equator $(8)$ are remarkably undisturbed by wave action, suggesting that waves were damped by sea ice (9). On the other hand, ice-free land area is indicated by the presence of aeolian dune fields and periglacial sand-wedge polygons (10). The existence of both ice-covered and ice-free land surfaces points to a complex interplay between sublimation, accretion and lateral flowage of ice under changing climatic conditions attending the progressive buildup of atmospheric $\mathrm{CO}_{2}$ in a snowball Earth.

The Ghaub glaciation in Namibia lacks thick glacial deposits, incised paleovalleys, faceted and striated stones, and outwash deposits. These features can be attributed to the fact that this area was part of a vast, shallowwater, tropical platform (1), lacking highlands on which ice would be subaerially accreted in a snowball Earth. The glacial deposits are derived from the directly underlying platformal carbonates and consist of debris advected upward from the sea bed by grounded sea ice. Sublimation at the surface and freezing at the base drove continual upward advection of the ice in which the debris was entrained. The debris was released mostly when the sea ice dissipated at the end of the snowball period, although some could have been released earlier as atmospheric concen- trations of $\mathrm{CO}_{2}$ rose causing sea ice to thin. In contrast, the older Chuos glaciation in Namibia occurred at a time of tectonic instability and significant topography. The Chuos glacial deposits are locally thick $(>1 \mathrm{~km})$, fill incised paleovalleys ( $<180 \mathrm{~m}$ deep), contain faceted and striated stones derived from distal sources, including crystalline basement, and are associated with outwash deposits $(1,11)$. Both the Chuos and Ghaub glaciations in Namibia have cap carbonates and negative carbon-isotope anomalies (the prime subjects of our report), for which Christie-Blick et al. do not offer an alternative explanation to a snowball Earth.

Christie-Blick et al. also question our interpretation of low carbon isotopic $\left(\delta^{13} \mathrm{C}\right)$ values in the cap carbonate above the glacial deposits, asserting that they require the ocean to be essentially lifeless for an extended time period after snowball conditions had ceased. The $\delta^{13} \mathrm{C}$ value of marine carbonate reflects the relative amounts of carbonate carbon and organic carbon burial in sediments. In our hypothesis, the low $\delta^{13} \mathrm{C}$ values reflect high rates of carbonate precipitation resulting from intense chemical weathering in the extreme greenhouse conditions following the melting of sea ice. If the rate of alkalinity delivery to seawater, and hence carbonate accumulation, was very high, recovery of biological productivity could be instantaneous after the deglaciation, and reach levels even greater than modern, but still not affect significantly the $\delta^{13} \mathrm{C}$ values of the cap carbonates.

Paul F. Hoffman

Daniel P. Schrag

Department of Earth and Planetary Sciences,
Harvard University, 20 Oxford Street,

Cambridge, MA 02138, USA

E-mail:hoffman@eps.harvard.edu

References

1. P. F. Hoffman, A. J. Kaufman, G. P. Halverson, D. P. Schrag, Science 281, 1342 (1998).

2. M. J. Kennedy, B. Runnegar, A. R. Prave, K.-H. Hoffmann, M. A. Arthur, Geology 26, 1059 (1998).

3. W. V. Preiss, The Adelaide Geosyncline (Geol. Surv. South Australia Bull. 53, Adelaide, 1987); G. M. Young and V. A. Gostin, Geol. Soc. Am. Bull. 101, 834 (1989); I. A. Dyson and C. C. von der Borch, in Incised-Valley Systems: Origin and Sedimentary Sequences, R. W. Dalrymple, R. Boyd, B. A. Zaitlin, Eds. (Society of Sedimentary Geology, Spec. Publ. 51, Tulsa, OK, 1994), pp. 209-222; M. Levy, N. ChristieBlick, P. K. Link, in ibid., pp. 369-382.

4. G. M. Young and V. A. Gostin, Precambrian Res. 39 , 151 (1988); M. N. Lemon and V. A. Gostin, in The Evolution of a Late Precambrian-Early Palaeozoic Rift Complex: The Adelaide Geosyncline, J. B. Jago and P. S. Moore, Eds. (Geological Society of Australia, Spec. Publ. 16, Sydney, Australia, 1990), pp. 149-163.

5. L. E. Sohl, N. Christie-Blick, D. V. Kent, Geol. Soc. Am. Bull., in press.

6. G. R. North, R. F. Cahalan, J. A. Coakley, Jr., Rev. Geophys. Space Phys. 19, 91 (1981).

7. P. W. Schmidt and G. E. Williams, Earth Planet. Sci. Lett. 134, 107 (1995).

8. G. E. Williams, J. Geol. Soc. London 146, 97 (1989).

9. R. W. Dalrymple, personal communication.

10. M. Deynoux, Palaeogeogr. Palaeoclimat. Palaeoecol. 39, 55 (1982); G. E. Williams and D. G. Tonkin, Australian J. Earth Sci. 32, 287 (1985); J.-N. Proust and M. Deynoux, in The Earth's Glacial Record: Facies Models and Geodynamic Evolution, M. Deynoux et al., Eds. (Cambridge Univ. Press, Cambridge, 1994), pp. 121-144; G. E. Williams, Aust. J. Earth Sci. 45, 733 (1998).

11. K.-H. Hoffmann and A. R. Prave, Communs. Geol. Surv. Namibia 11, 47 (1996); P. F. Hoffman, A. J. Kaufman, G. P. Halverson, GSA Today 8 (no. 9), 1 (1998).

12. We thank R. B. Alley, W. S. Broecker, and R. W. Dalrymple for insightful comments.

8 March 1999; accepted 26 March 1999 